\title{
EVALUATION OF ALTERNATIVE CONSTRUCTION SITES WITH ANAL YTIC NETWORK PROCESS METHOD
}

\author{
Li-Chung Chao \\ National Kaohsiung First University of Science and Technology \\ Kaohsiung, Taiwan ROC \\ E-mail: chaolc@nkfust.edu.tw
}

\begin{abstract}
In evaluating housing projects, developers often have several sites as alternatives for development. Assessing each site so as to identify the best for implementation is their most important decision in the project planning stage. The traditional net present worth method has difficulty in including intangible benefits and risks, so the result of it may not represent the overall value of an alternative. The multiattribute utility theory method can include all factors in producing a total utility score for an alternative, but it has difficulty in determining criteria weights and utility functions. The analytic hierarchy process method can derive criteria weights and priority scores of alternatives from paired comparisons, but it is incapable of incorporating feedback relations between criteria and alternatives as it is done hierarchically in a top-down manner. This paper proposes an improved model for assessing alternative sites using the analytic network process method as the generalized analytic hierarch process method to include the feedback impacts absent from the analytic hierarch process. To illustrate the model, three recent housing projects in Kaohsiung, Taiwan were used as hypothetical alternative sites being considered by a medium developer. A study of related factors that influenced the sites' economics as well as feedback relations between factors and alternatives were conducted to determine the criteria and the dependency links in the network model. Based on company and project conditions, values of inputs for the model were set and were processed to produce the criteria weights and the relative scores of the alternatives for establishing their priority ordering. The ANP model results in changes in the ranking of the sites from those produced by the AHP method due to the additional relations.
\end{abstract}

Keywords: housing project, site selection, decision analysis, analytic network process

\section{Introduction}

In evaluating housing projects, developers often have several sites as alternatives for development. Assessing each site so as to identify the best for implementation is their most important decision in the project planning stage. The traditional net present worth method has difficulty in including intangible benefits and risks, so the result of it may not represent the overall value of an alternative. The multiattribute utility theory method can include all factors in producing a total utility score for an alternative, but it has difficulty in determining criteria weights and utility functions. The analytic hierarchy process (AHP) method can derive criteria weights and priority scores of alternatives from paired comparisons, but it cannot incorporate feedback relations between criteria and alternatives as it is done hierarchically in a top-down manner. This paper proposes an improved model for assessing alternative sites using the analytic network process (ANP) method of Saaty (1996) as the generalized AHP method to include the feedback impacts absent from the AHP. The ANP method has found increasing application, e.g. Meade and Sarkis (1998), Meade and Presley (2002), Cheng and Li (2004), Mu (2006). To illustrate the proposed model, three recent housing projects in Kaohsiung, Taiwan were used as hypothetical alternative sites being considered by a medium developer. In the following, we start with the AHP model and then extend it into the ANP model; the assessments made by the two are compared. 


\section{The AHP model}

Compared to traditional multi-attribute decision analysis techniques such as utility theory, the analytical hierarchy process of Saaty (1980) is a relatively informal approach to decision-making problems and has been applied to a variety of problems, e.g. Skibniewski and Chao (1992), Cheung et al (2001). The AHP helps decision makers to identify and set priorities on the basis of their objectives and their knowledge and experience. The AHP framework organizes their feelings and intuitive judgments as well as logic so that they can map out complex situations as per their perception. The AHP method for solution begins with structuring a complex problem by decomposing it into a hierarchy to include all attribute elements reflecting the goals and concerns of the decision maker. Next, elements are compared in a systematic manner using the same 1-9 scale to measure their relative importance and the overall priorities among the elements within the hierarchy are established, while the relative standing of each alternative with respect to each criterion element is determined using the same scale. The overall score of each alternative can then be aggregated, while the consistency in making comparisons can be measured using Saaty's (1980) consistency ratio.

\subsection{The hierarchy and comparison matrices}

The proposed model for evaluating alternative construction sites is a hierarchy of evaluation elements as shown in Figure 1, which is used as an illustrative example for site selection for terraced houses.

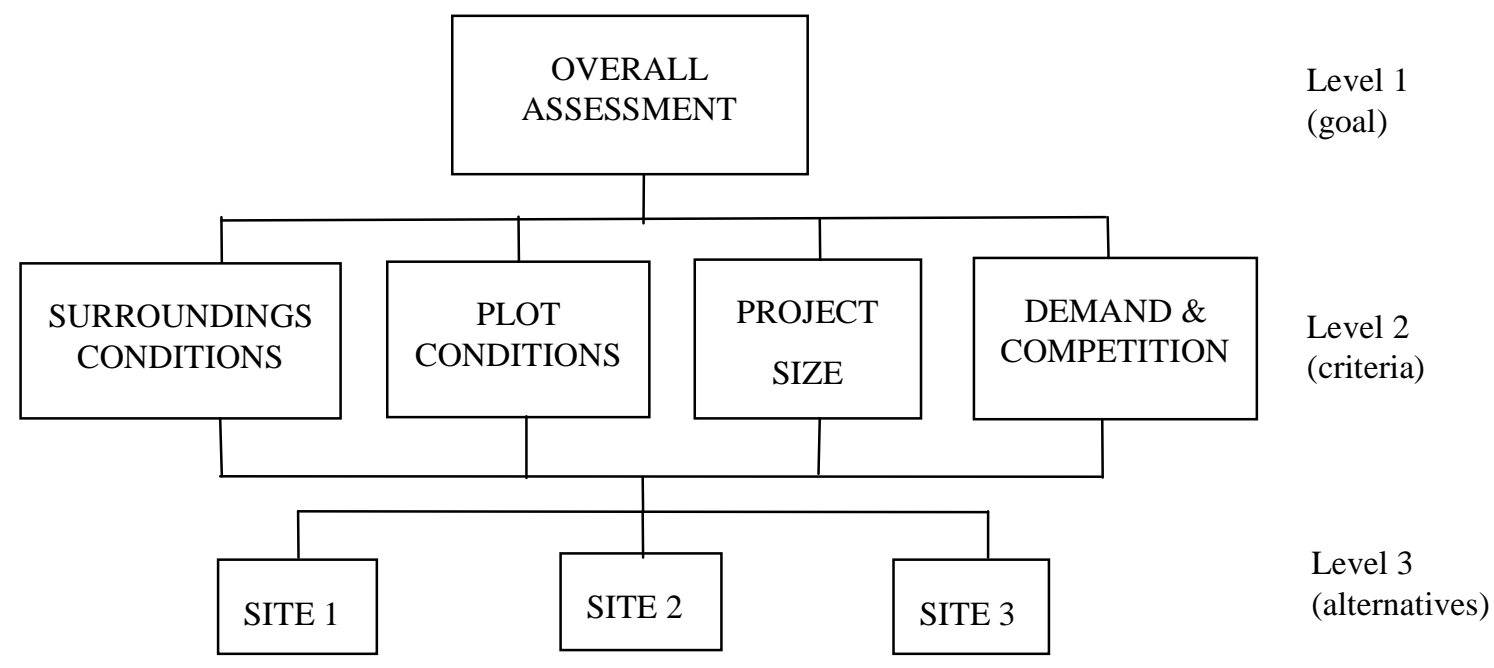

Figure 1. Decision attribute hierarchy for the example site selection problem

The four criteria at level 2 of the hierarchy are surroundings conditions, plot conditions, project size, and demand and competition, reflecting the goals and concerns of a developer for the site selection problem. Surroundings conditions refer to a site's external physical environments including completeness of transport systems, access to public transports, availability of public facilities such as schools, markets, and services, distance to unfavorable places such as cemetery and landfills. Plot conditions refer to a site's suitability for housing development concerning plot shape, terrain, and ground conditions. Project size refers to the gross floor area buildable for a site according to its acreage and land use regulations. Demand and competition refer to potential of, and threat to, respectively, sales for new housing in the area. Table 1 gives the comparison matrix for surroundings conditions, plot conditions, project size, and demand and competition in their influence on overall assessment for site selection as perceived by the developer, with the eigenvector showing that surroundings conditions have the greatest weight $(0.455)$, followed by demand and competition (0.263), plot conditions (0.141) and project size (0.141). 


\section{L.-C. Chao/ Evaluation of alternative construction sites with ANP method}

Table 1. Comparison of criteria in their influence on overall assessment.

\begin{tabular}{|l|c|c|c|c|c|}
\hline Attributes & $\begin{array}{c}\text { Surroundings } \\
\text { Conditions }\end{array}$ & $\begin{array}{c}\text { Plot } \\
\text { Conditions }\end{array}$ & Project Size & $\begin{array}{c}\text { Demand \& } \\
\text { Competition }\end{array}$ & $\begin{array}{c}\text { Principal } \\
\text { Eigenvector }\end{array}$ \\
\hline $\begin{array}{l}\text { Surroundings } \\
\text { Conditions }\end{array}$ & 1 & 3 & 3 & 2 & 0.455 \\
\hline Plot Conditions & $1 / 3$ & 1 & 1 & $1 / 2$ & 0.141 \\
\hline Project Size & $1 / 3$ & 1 & 1 & $1 / 2$ & 0.141 \\
\hline $\begin{array}{l}\text { Demand \& } \\
\text { Competition }\end{array}$ & $1 / 2$ & 2 & 2 & 1 & 0.263 \\
\hline
\end{tabular}

The three sites at level 3 of the hierarchy are the alternatives being considered for constructing terraced houses. Based on the data collected, site 1 is assessed as above-average in all aspects: the surroundings, the plot itself, the size, and the demand and competition in the nearby area. Situated amongst intense construction activity under way, site 2 is assessed as excellent in surrounding conditions, but it is assessed as poor for the remaining three criteria, because of its shape and comparatively small acreage making efficient land use difficult and the risk of over-supply in the area. Site 3 is located at an outer corner of the city with high potential for housing development, and so, as the opposite of site 2 , it is assessed as poor in surrounding conditions, but very good in plot conditions, size, and in demand and competition. Tables 2 , 3,4 , and 5 gives the comparison matrices for the three sites in their performance on the four criteria, as per the opinions of the developer; the obtained eigenvectors show their differences in scores indicating their relative strengths and weaknesses as stated above.

Table 2: Comparison of alternative sites in their performance on surroundings conditions.

\begin{tabular}{|l|c|c|c|c|}
\hline Alternatives & Site 1 & Site 2 & Site 3 & Principal Eigenvector \\
\hline Site 1 & 1 & $1 / 2$ & 3 & 0.309 \\
\hline Site 2 & 2 & 1 & 5 & 0.581 \\
\hline Site 3 & $1 / 3$ & $1 / 5$ & 1 & 0.110 \\
\hline
\end{tabular}

Table 3: Comparison of alternative sites in their performance on plot conditions.

\begin{tabular}{|l|c|c|c|c|}
\hline Alternatives & Site 1 & Site 2 & Site 3 & Principal Eigenvector \\
\hline Site 1 & 1 & 3 & 1 & 0.429 \\
\hline Site 2 & $1 / 3$ & 1 & $1 / 3$ & 0.143 \\
\hline Site 3 & 1 & 3 & 1 & 0.429 \\
\hline
\end{tabular}

Table 4: Comparison of alternative sites in their performance on project size.

\begin{tabular}{|l|c|c|c|c|}
\hline Alternatives & Site 1 & Site 2 & Site 3 & Principal Eigenvector \\
\hline Site 1 & 1 & 3 & $1 / 2$ & 0.320 \\
\hline Site 2 & $1 / 3$ & 1 & $1 / 4$ & 0.122 \\
\hline Site 3 & 2 & 4 & 1 & 0.558 \\
\hline
\end{tabular}

Table 5: Comparison of alternative sites in their performance on demand \& competition

\begin{tabular}{|l|c|c|c|c|}
\hline Alternatives & Site 1 & Site 2 & Site 3 & Principal Eigenvector \\
\hline Site 1 & 1 & 2 & $1 / 2$ & 0.311 \\
\hline Site 2 & $1 / 2$ & 1 & $1 / 2$ & 0.196 \\
\hline Site 3 & 2 & 2 & 1 & 0.493 \\
\hline
\end{tabular}




\subsection{Aggregation of comparison results}

The aggregation of comparison results, i.e. eigenvectors, can be accomplished by means of vector multiplication as below.

$S_{j}=\sum_{i=1}^{5} w_{i} S_{j i}$

where $S_{j}=$ site $j$ 's total score; $w_{i}=$ criterion $I$ 's weight; sji=site $j$ 's score on criterion $i$.

However, aggregation of AHP results can also be done by means of the limit matrix method used in analytic network process, as shown next. First, create a 8 by 8 matrix in which each row (and column) corresponds to each of the eight attributes in the hierarchy in Figure 1, and then insert all the five eigenvectors obtained above into their corresponding columns and insert zeros where there is no dependency relation between the attributes, resulting in an initial super-matrix, $W$, as shown in Table 6 . Notice that at the right-bottom area, there is an identity sub-matrix for the three sites, making sure that the matrix is so-called column stochastic, i.e. the sum of every column is one. Then, to obtain the sites' total scores, raise the power of the matrix until the product of multiplication converges, i.e. no change occurs. For more details, see Saaty (1996) and Saaty (2005). The limit matrix is represented as:

$$
\lim _{k \rightarrow \infty} W^{k}
$$

Since there is no feedback relation in the hierarchy in Figure 1 , convergence occurs at $\mathrm{k}=2$. Table $7\left(W^{2}\right)$ contains the three's total scores in the overall assessment column, showing that site 2 is rated the highest at 0.353 , because of its superior score in the most important criterion, surroundings conditions, which more than compensate for its shortcomings in plot conditions, project size, and demand and competition. In contrast, site 3 is rated the lowest at 0.319 because it scores the least in surroundings conditions, which cannot be offset by its high scores in the remaining criteria. Rated at 0.328 , site 2 ranks second for its generally good performance in all aspects.

Table 6. Initial super-matrix for the AHP example, $W$.

\begin{tabular}{|l|c|c|c|c|c|c|c|c|}
\hline Attributes & $\begin{array}{c}\text { Overall } \\
\text { Assessment }\end{array}$ & $\begin{array}{c}\text { Surroundings } \\
\text { Conditions }\end{array}$ & $\begin{array}{c}\text { Plot } \\
\text { Conditions }\end{array}$ & $\begin{array}{c}\text { Project } \\
\text { Size }\end{array}$ & $\begin{array}{c}\text { Demand \& } \\
\text { Competition }\end{array}$ & Site 1 & Site 2 & Site 3 \\
\hline $\begin{array}{l}\text { Overall } \\
\text { Assessment }\end{array}$ & 0 & 0 & 0 & 0 & 0 & 0 & 0 & 0 \\
\hline $\begin{array}{l}\text { Surroundings } \\
\text { Conditions }\end{array}$ & 0.455 & 0 & 0 & 0 & 0 & 0 & 0 & 0 \\
\hline $\begin{array}{l}\text { Plot } \\
\text { Conditions }\end{array}$ & 0.141 & 0 & 0 & 0 & 0 & 0 & 0 & 0 \\
\hline Project Size & 0.141 & 0 & 0 & 0 & 0 & 0 & 0 & 0 \\
\hline $\begin{array}{l}\text { Demand \& } \\
\text { Competition }\end{array}$ & 0.263 & 0 & 0 & 0 & 0 & 0 & 0 & 0 \\
\hline Site 1 & 0 & 0.309 & 0.429 & 0.320 & 0.311 & 1 & 0 & 0 \\
\hline Site 2 & 0 & 0.581 & 0.143 & 0.122 & 0.196 & 0 & 1 & 0 \\
\hline Site 3 & 0 & 0.110 & 0.429 & 0.558 & 0.493 & 0 & 0 & 1 \\
\hline
\end{tabular}




\section{L.-C. Chao/ Evaluation of alternative construction sites with ANP method}

Table 7. Limit super-matrix for the AHP example, $W^{2}$.

\begin{tabular}{|l|c|c|c|c|c|c|c|c|}
\hline Attributes & $\begin{array}{c}\text { Overall } \\
\text { Assessment }\end{array}$ & $\begin{array}{c}\text { Surroundings } \\
\text { Conditions }\end{array}$ & $\begin{array}{c}\text { Plot } \\
\text { Conditions }\end{array}$ & $\begin{array}{c}\text { Project } \\
\text { Size }\end{array}$ & $\begin{array}{c}\text { Demand \& } \\
\text { Competition }\end{array}$ & Site 1 & Site 2 & Site 3 \\
\hline $\begin{array}{l}\text { Overall } \\
\text { Assessment }\end{array}$ & 0 & 0 & 0 & 0 & 0 & 0 & 0 & 0 \\
\hline $\begin{array}{l}\text { Surroundings } \\
\text { Conditions }\end{array}$ & 0 & 0 & 0 & 0 & 0 & 0 & 0 & 0 \\
\hline $\begin{array}{l}\text { Plot } \\
\text { Conditions }\end{array}$ & 0 & 0 & 0 & 0 & 0 & 0 & 0 & 0 \\
\hline Project Size & 0 & 0 & 0 & 0 & 0 & 0 & 0 & 0 \\
\hline $\begin{array}{l}\text { Demand \& } \\
\text { Competition }\end{array}$ & 0 & 0 & 0 & 0 & 0 & 0 & 0 & 0 \\
\hline Site 1 & 0.328 & 0.309 & 0.429 & 0.320 & 0.311 & 1 & 0 & 0 \\
\hline Site 2 & 0.353 & 0.581 & 0.143 & 0.122 & 0.196 & 0 & 1 & 0 \\
\hline Site 3 & 0.319 & 0.110 & 0.429 & 0.558 & 0.493 & 0 & 0 & 1 \\
\hline
\end{tabular}

\section{The ANP model}

The above analysis is lop-sided due to the domination of one criterion, i.e. surroundings conditions, - the so called location effect. Not satisfied with the result, the developer re-considers the characteristics of the three sites and decides to incorporate feedback relations in the model thus making it an ANP model.

\subsection{Additional comparison matrices}

Besides comparing the four criteria in their influence on overall assessment in Table 1, three more comparison matrices are created for assessing the relative importance of the four criteria with respect to site 1 (Table 8), site 2 (Table 9), and site 3 (Table 10). Since the site alternatives occupy the bottom level of the hierarchy in Figure 1, these matrices define the feedback relations between the criteria and the alternatives in addition to the dependency relations between the criteria and the alternatives defined previously in Tables 2, 3, 4, and 5. The feedback relations are considered important for the construction site selection problem because it is a tough evaluation that involves uncertainty in determining the priority of the criteria given the strengths and weaknesses of each alternative available. As shown in the obtained principal eigenvectors in Tables $8,9,10$, varying weights for surroundings conditions, plot conditions, project size, and demand and competition are generated. In each of these eigenvectors, greater weights reflect the developer's concerns for the relative weaknesses of the respective site, while a smaller weight reflects the opposite, i.e. the site's relative strength. When the three eigenvectors are added to the model, they represent challenges to the superiority of each site and will influence the resulting scores.

Table 8. Comparison of criteria in their importance with respect to site 1 .

\begin{tabular}{|l|c|c|c|c|c|}
\hline Attributes & $\begin{array}{c}\text { Surroundings } \\
\text { Conditions }\end{array}$ & $\begin{array}{c}\text { Plot } \\
\text { Conditions }\end{array}$ & Project Size & $\begin{array}{c}\text { Demand \& } \\
\text { Competition }\end{array}$ & $\begin{array}{c}\text { Principal } \\
\text { Eigenvector }\end{array}$ \\
\hline $\begin{array}{l}\text { Surroundings } \\
\text { Conditions }\end{array}$ & 1 & 1.5 & 1 & 1 & 0.273 \\
\hline Plot Conditions & $1 / 1.5$ & 1 & $1 / 1.5$ & $1 / 1.5$ & 0.182 \\
\hline Project Size & 1 & 1.5 & 1 & 1 & 0.273 \\
\hline $\begin{array}{l}\text { Demand \& } \\
\text { Competition }\end{array}$ & 1 & 1.5 & 1 & 1 & 0.273 \\
\hline
\end{tabular}


Table 9. Comparison of criteria in their importance with respect to site 2.

\begin{tabular}{|l|c|c|c|c|c|}
\hline Attributes & $\begin{array}{c}\text { Surroundings } \\
\text { Conditions }\end{array}$ & $\begin{array}{c}\text { Plot } \\
\text { Conditions }\end{array}$ & Project Size & $\begin{array}{c}\text { Demand \& } \\
\text { Competition }\end{array}$ & $\begin{array}{c}\text { Principal } \\
\text { Eigenvector }\end{array}$ \\
\hline $\begin{array}{l}\text { Surroundings } \\
\text { Conditions }\end{array}$ & 1 & $1 / 2$ & $1 / 2$ & $1 / 2$ & 0.143 \\
\hline Plot Conditions & 2 & 1 & 1 & 1 & 0.286 \\
\hline Project Size & 2 & 1 & 1 & 1 & 0.286 \\
\hline $\begin{array}{l}\text { Demand \& } \\
\text { Competition }\end{array}$ & 2 & 1 & 1 & 1 & 0.286 \\
\hline
\end{tabular}

Table 10. Comparison of criteria in their importance with respect to site 3.

\begin{tabular}{|l|c|c|c|c|c|}
\hline Attributes & $\begin{array}{c}\text { Surroundings } \\
\text { Conditions }\end{array}$ & $\begin{array}{c}\text { Plot } \\
\text { Conditions }\end{array}$ & Project Size & $\begin{array}{c}\text { Demand \& } \\
\text { Competition }\end{array}$ & $\begin{array}{c}\text { Principal } \\
\text { Eigenvector }\end{array}$ \\
\hline $\begin{array}{l}\text { Surroundings } \\
\text { Conditions }\end{array}$ & 1 & 2 & 2 & 2 & 0.400 \\
\hline Plot Conditions & $1 / 2$ & 1 & 1 & 1 & 0.200 \\
\hline Project Size & $1 / 2$ & 1 & 1 & 1 & 0.200 \\
\hline $\begin{array}{l}\text { Demand \& } \\
\text { Competition }\end{array}$ & $1 / 2$ & 1 & 1 & 1 & 0.200 \\
\hline
\end{tabular}

\subsection{Super-matrices and final ranking}

As shown in Table 11, the eigenvectors from Tables 8, 9, and 10 are inserted into their corresponding columns of the initial super-matrix, while the previous identity sub-matrix is deleted and everything else is retained. Then, the power of the matrix is raised until the product of multiplication converges at $\mathrm{k}=10$. As shown in Table 12, the ranking of the three sites from first to third has now changed to site 3 , site 1 , and site 2, versus site 2, site 1, and site 3 from the previous AHP analysis. The changes in the three sites' scores are due to changes in the criteria weights, as a result of the feedback relations added. Compared to the previous criteria weights of $0.455,0.141,0.141$, and 0.263 , the final criteria weights of $0.286,0.218$, 0.248 , and 0.248 show moderated differences among them, also as a result of the feedback relations.

Table 11. Initial super-matrix for the ANP example, $W$.

\begin{tabular}{|l|c|c|c|c|c|c|c|c|}
\hline Attributes & $\begin{array}{c}\text { Overall } \\
\text { Assessment }\end{array}$ & $\begin{array}{c}\text { Surroundings } \\
\text { Conditions }\end{array}$ & $\begin{array}{c}\text { Plot } \\
\text { Conditions }\end{array}$ & $\begin{array}{c}\text { Project } \\
\text { Size }\end{array}$ & $\begin{array}{c}\text { Demand \& } \\
\text { Competition }\end{array}$ & Site 1 & Site 2 & Site 3 \\
\hline $\begin{array}{l}\text { Overall } \\
\text { Assessment }\end{array}$ & 0 & 0 & 0 & 0 & 0 & 0 & 0 & 0 \\
\hline $\begin{array}{l}\text { Surroundings } \\
\text { Conditions }\end{array}$ & 0.455 & 0 & 0 & 0 & 0 & 0.273 & 0.143 & 0.400 \\
\hline $\begin{array}{l}\text { Plot } \\
\text { Conditions }\end{array}$ & 0.141 & 0 & 0 & 0 & 0 & 0.182 & 0.286 & 0.200 \\
\hline Project Size & 0.141 & 0 & 0 & 0 & 0 & 0.273 & 0.286 & 0.200 \\
\hline $\begin{array}{l}\text { Demand \& } \\
\text { Competition }\end{array}$ & 0.263 & 0 & 0 & 0 & 0 & 0.273 & 0.286 & 0.200 \\
\hline Site 1 & 0 & 0.309 & 0.429 & 0.320 & 0.311 & 0 & 0 & 0 \\
\hline Site 2 & 0 & 0.581 & 0.143 & 0.122 & 0.196 & 0 & 0 & 0 \\
\hline
\end{tabular}




\begin{tabular}{|l|l|l|l|l|l|l|l|l|}
\hline Site 3 & 0 & 0.110 & 0.429 & 0.558 & 0.493 & 0 & 0 & 0 \\
\hline
\end{tabular}

Table 12. Limit super-matrix for the ANP example, $W^{10}$.

\begin{tabular}{|l|c|c|c|c|c|c|c|c|}
\hline Attributes & $\begin{array}{c}\text { Overall } \\
\text { Assessment }\end{array}$ & $\begin{array}{c}\text { Surroundings } \\
\text { Conditions }\end{array}$ & $\begin{array}{c}\text { Plot } \\
\text { Conditions }\end{array}$ & $\begin{array}{c}\text { Project } \\
\text { Size }\end{array}$ & $\begin{array}{c}\text { Demand \& } \\
\text { Competition }\end{array}$ & Site 1 & Site 2 & Site 3 \\
\hline $\begin{array}{l}\text { Overall } \\
\text { Assessment }\end{array}$ & 0 & 0 & 0 & 0 & 0 & 0 & 0 & 0 \\
\hline $\begin{array}{l}\text { Surroundings } \\
\text { Conditions }\end{array}$ & 0 & 0.286 & 0.286 & 0.286 & 0.286 & 0 & 0 & 0 \\
\hline $\begin{array}{l}\text { Plot } \\
\text { Conditions }\end{array}$ & 0 & 0.218 & 0.218 & 0.218 & 0.218 & 0 & 0 & 0 \\
\hline Project Size & 0 & 0.248 & 0.248 & 0.248 & 0.248 & 0 & 0 & 0 \\
\hline $\begin{array}{l}\text { Demand \& } \\
\text { Competition }\end{array}$ & 0 & 0.248 & 0.248 & 0.248 & 0.248 & 0 & 0 & 0 \\
\hline Site 1 & 0.338 & 0 & 0 & 0 & 0 & 0.338 & 0.338 & 0.338 \\
\hline Site 2 & 0.276 & 0 & 0 & 0 & 0 & 0.276 & 0.276 & 0.276 \\
\hline Site 3 & 0.386 & 0 & 0 & 0 & 0 & 0.386 & 0.386 & 0.386 \\
\hline
\end{tabular}

\section{Conclusions}

Although the AHP method is used widely in decision analysis, it allows only bottom-up, one-way influences in the hierarchy since it cannot incorporate feedback and other dependency relations among the criteria and alternatives. On the other hand, as the generalized AHP method, the ANP method does allow multi-direction relations among the elements and evaluates the impacts of all relations on the final assessment. In the example of the present study of construction site selection for housing development, both the hierarchical relations between adjacent levels and the feedback relations between the criteria and the alternatives are included in the proposed ANP model to determine the ranking of alternative sites. Based on the characteristics of the alternative sites under evaluation, adding the feedback relations has the effect of redistributing the weights more evenly among the four criteria. The proposed model results in changes in the ranking of the sites from those produced by the AHP method due to the additional relations. However, because of the increased complexity, use of ANP for the site selection problem requires discretion and is only justified by situations where it is important to include such extra links in the analysis. Further validation of the model by comparing the model with conventional methods is suggested.

\section{REFERENCES}

Cheng, E. W. L., and Li, H. (2004). Contractor selection using the analytic network process. Construction Management and Economics, 22(10), 1047-1056.

Cheung, S.-O., Lam, T.-I., Leung, M.-Y., and Wan, Y.-W. (2001). “An analytical hierarchy process based procurement selection method." Construction Management and Economics, 19, 427-437. 
Meade, L. M., and Sarkis, J. (1998). "Strategic analysis of logistics and supply chain management systems using the analytic network analysis." Transportation Research Part E: Logistics and Transportation Review, 34(3), 201-215.

Meade, L. M., and Presley, A. (2002). "R\&D project selection using the analytic network process." IEEE Transactions in Engineering Management, 49(1), 59-66.

$\mathrm{Mu}$, E. (2006). A unified framework for site selection and business forecasting using ANP. Journal of Systems Science and Systems Engineering, 15(2), 178-188.

Saaty, T.L. (1980). The Analytical Hierarchy Process. McGraw Hill.

Saaty, T.L. (1996). Decision Making with Dependence and Feedback: The Analytic Network Process. RWS Publications.

Saaty, T. L. (2005). Theory and Applications of the Analytic Network Process: Decision Making with Benefits, Opportunities, Costs and Risks. RWS Publications.

Skibniewski, M. J., and Chao, L.-C. (1992). "Evaluation of advanced construction technology with AHP method." Journal of Construction Engineering and Management, 118(3), 577-593. 